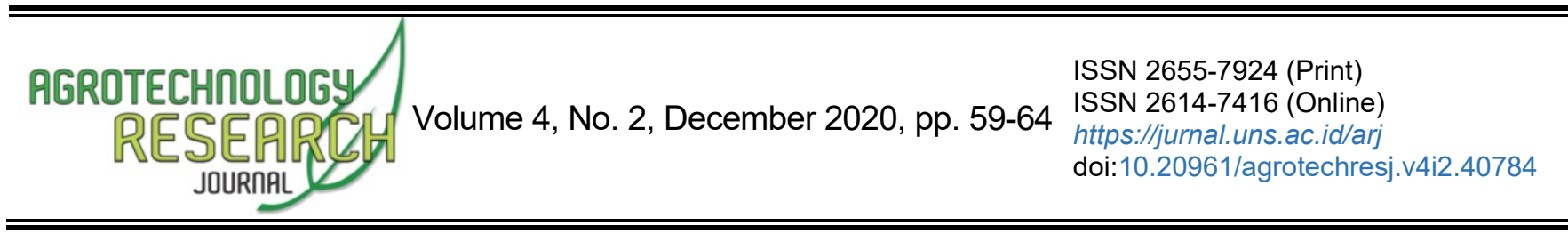

\title{
Application of Empty Fruit Bunches Compost and Types of P Fertilizer on the Growth and Phosphorus Uptake in Oil Palm Seedlings
}

\author{
Pauliz Budi Hastuti ${ }^{*}$, Sri Manu Rohmiyati² \\ ${ }^{1,2}$ Faculty of Agriculture, Institut Pertanian Stiper, Sleman, Yogyakarta, Indonesia
}

Received 12 March 2020; Accepted 1 July 2020; Published 1 December 2020

\begin{abstract}
This research aimed to evaluate the effect of empty fruit bunches (efb) compost, phosphate-solubilizing bacteria (PSB), lime, and types of $\mathrm{P}$ fertilizer on the growth and availability of Phosphorus and $\mathrm{P}$ uptake in the pre-nursery (PN) oil palm seedlings in latosols. The pot experiments were arranged in a Factorial Completely Randomized method. The first factor was the application of efb compost: without efb compost, efb compost, without efb compost + PSB, and without efb compost + lime. The second factor was the types of P fertilizer: SP-36, RP, guano, and NPKMg + Urea as a control. The results showed that the combination of without efb compost +lime and RP fertilizer produces the highest number of leaves. The influence of a single factor showed that the application of without efb, efb compost, without efb compost +PSB, without efb compost + lime, resulted in the same growth of seedlings, except on plant height and the length of the leaf. The various types of $P$ fertilizer led to the same growth of seedlings except for stem diameter. The highest available P was obtained in the combination of without efb compost + PSB with SP-36 fertilizer, which was $631.1 \%$ compared to control (without efb compost and NPKMg, Urea) and the lowest in the combination of without efb compost + lime with (NPKMg, Urea). The treatment without efb compost + lime with SP-36 fertilizer increased $\mathrm{P}$ uptake of leaves by $55.6 \%$ and stem by $47.1 \%$ compared to control.
\end{abstract}

Keywords: Efb compost; Latosols; Prenursery; P fertilizer

Cite This As (CSE Style): Hastuti PB, Rohmiyati SM. 2020. Application of Empty Fruit Bunches Compost and Types of P Fertilizer on the Growth and Phosphorus Uptake in Oil Palm Seedlings. Agrotech Res J. 4(2): 59-64. https://doi.org/10.20961/agrotechresj.v4i2.40784

\section{INTRODUCTION}

Oil palm (Elaeis guineensis Jacq) is one of the plantation crops that plays an important role in a plantation sub-sector. Currently, Indonesia becomes the best country that produces oil palm in the world. The area of oil palm plantations in Indonesia in 2015 reached $11,260,277$ ha with a production of CPO (Crude Palm Oil) amounted to $31,070,015$ tons (Directorate General of Estate Crops 2016). In order to yield higher palm oil production, high rainfall conditions throughout the year are needed. This leads to the formation of acid soils due to the very intensive leaching of alkaline cations $(\mathrm{Ca}, \mathrm{Mg}$, $\mathrm{K}, \mathrm{Na}$ ). Latosols is one of the acid soils which are very widespread in Indonesia. It has a $\mathrm{pH}$, cation exchange capacity (CEC), and a low base saturation level. However, the content of aluminum (Al saturation), iron, and manganese retards plant growth. Also, it contributes to so high $P$ fixation that the availability of $P$ in the soil is low. In addition, this soil is vulnerable to erosion and has low organic matter content resulting in poor biotic elements. Phosphorus is a limiting factor in crop

${ }^{*}$ Corresponding Author:

E-Mail: pauliz@instiperjogja.ac.id productivity due to low solubility in acid soils because it is fixed by micro metal elements (Fe-P; Al-P). In the process of decomposition, organic matter produces humic acid and organic acid bound with $\mathrm{Fe}$ and $\mathrm{Al}$ so that the fixated $P$ can be detached (Siddiqui et al. 2009). Furthermore, Walsh and McDonnell (2012) contend that organic matter will improve CEC and can form a chelated cation.

To enhance the growth of oil palm seedlings in acidic soils, such as latosols, it is required to use soilrevitalizing materials such as composted organic materials (efb), dolomite lime, phosphate-solubilizing bacteria, and $P$ fertilizer because these are low in latosols. Soil improvement or ameliorant is an ingredient added to the soil to stimulate or aid the growth of plant roots. The utilization of ameliorants is needed as a source of nutrients to reduce soil acidity and as a source of binding or absorbing cations leached into other areas due to water regulation. The effectiveness of ameliorants depends on the quality of materials, especially the chemical composition. Ameliorant effectiveness can be improved by mixing several ameliorant ingredients (Maftu'ah et al. 2013).

One of the nutrients required by plants is phosphorus $(\mathrm{P})$, following nitrogen. Phosphorus is a limiting factor in crop productivity due to the low dissolution of the soil 
concentration, as high $\mathrm{P}$ fixation on the soil provides little P (Ritonga et al. 2015). Plants need it as a constituent of ATP that serves as a source of energy for the process of metabolism in plants and stimulates the growth and development of fine roots that are very important in the process of seedling growth. Various types of fertilizer $P$, such as SP-36, RP (Rock Phosphate), and guano generally have low solubility compared to other inorganic fertilizers. For this reason, to boost the degree of solubility, microbes, and organic material such as oil palm empty fruit bunch compost can be used.

Oil palm empty fruit bunches can improve soil improvement quality and serve as a nutrient source for cultivated plants or crops. Efb contains $0.91 \% \mathrm{~N}, 2.13 \%$ $\mathrm{P}$ and $6.68 \% \mathrm{~K}$ Siddiquee et al. ( 2017), other writers said that efb nutrient contents : $42.8 \% \mathrm{C}, 6.3 \%$ ash, 0.30 $\% \mathrm{MgO}, 0.25 \% \mathrm{CaO}, 10 \mathrm{mg} / \mathrm{kg} \mathrm{B}, 23 \mathrm{mg} / \mathrm{kg} \mathrm{Cu}, 51$ $\mathrm{mg} / \mathrm{kg} \mathrm{Zn,} 473 \mathrm{mg} / \mathrm{kg} \mathrm{Fe}$ and $48 \mathrm{mg} / \mathrm{kg} \mathrm{Mn} \mathrm{(Corley} \mathrm{and}$ Tinker 2015). The application of oil palm plantation waste or residue in nursery media not only serves as a supplement to plant nutrients, but also maintains soil fertility and the physical, chemical, and biological properties of soil, which provide plants with sufficient water and good soil aeration during growth.

In addition, organic materials can increase a sufficient amount and activity of soil microbes (Siddiqui et al. 2009). Naturally, there are endogenous microbes in the rhizosphere that can provide $P$ nutrients (Lestari et al. 2011). Applying $15 \%$ efb compost to regosols at a prenursery stage can replace the treatment of a standard dose of inorganic fertilizers (Hastuti and Rohmiyati 2016). The result of (Ritonga et al. 2015) showed that phosphate solubilizing Microbe (fungi) and chicken manure application increased $P$ availability and productions of potato (Solanum tuberosum L.) plants. By composting oil palm empty fruit bunches as a food base for endogenous $P$ solubilizing microbes, $P$ for oil palm seedlings to the main nursery will be available. The application of this compost will increase the solubility of $P$ in acid soils such as latosols that will enhance the effectiveness of fertilization in oil palm cultivation (seedlings). Although many studies have investigated the effects of organic materials on crop growth and productivity, more research is needed to examine different organic materials (Damanik et al. 2011). To extend this body of research, the present study looks into the effect of oil palm empty fruit bunches compost, phosphate-solubilizing bacteria, lime, and $P$ fertilizer types on the increase of $P$ availability and $P$ uptake in a latosol-sited pre-nursery.

\section{MATERIALS AND METHODS}

The pot experiment was conducted at the Education and Research Garden, Institut Pertanian Stiper, Maguwoharjo, Sleman, D.I. Yogyakarta, Indonesia, in 2016. The research materials included oil palm $D \times P$ (Yangambi) seed varieties from Indonesian Oil Palm Research Institute Medan, efb compost obtained from PT. Makin in Central Kalimantan, phosphate-solubilizing bacteria (PSB) obtained from the Indonesian Research
Institute for Biotechnology and Bioindustry Bogor, urea, SP-36, RP (Rock Phosphate), guano, NPKMg (15-15-64), dolomite and latosols ( $\mathrm{pH} 4.5$ ) from Pathuk, Gunung Kidul D.I. Yogyakarta.

$P$ Fertilization in the pre-nursery was applicated at a dose of $0.04 \mathrm{~g} \mathrm{SP}-36$ seedling-1, 0,08 g RP seedling-1, and $0,06 \mathrm{~g}$ guano seedling-1. The fertilization was drilled and covered with thin soil. Phosphate-solubilizing bacteria with a dose of $10 \mathrm{~g}$ seedling-1 were given at the time of planting. The application of inorganic fertilizers (Urea and NPKMg 15-15-6-4) as control were given with a concentration of $2 \mathrm{~g}$ liters- 1 of water for 20 seedlings. NPKMg fertilizers were given at weeks $5,7,9$, and 11 and urea at weeks $6,8,10$, and $12.20 \mathrm{~g}$ of dolomite lime seedlings- 1 was given 3 days before giving $P$. fertilizer.

A Factorial Completely Randomized design was used in this research. It consisted of two factors application of efb compost and types of $P$ fertilizer. Application of efb compost consists of four levels ( $\mathrm{TO}=$ without compost, $\mathrm{T} 1=15 \%$ vol.efb compost, $\mathrm{T} 2=$ without compost + phosphate-solubilizing bacteria, T3=without compost + lime). While $P$ fertilizer types consist of four levels ( $P 1=0.04 \mathrm{~g} \mathrm{SP}-36, \mathrm{P} 2=0,08 \mathrm{~g} \mathrm{RP}, \mathrm{P} 3=0,06 \mathrm{~g}$ guano, and $\mathrm{P} 4=$ NPKMg and Urea as a control). Each of the combination treatments had ten replicated, giving a total of 160 experimental units. Observation parameters include plant height, stem diameter, the number of leaves, length of leaf, fresh plant weight and dry plant weight, root volume, fresh root weight and dry root weight, the levels of $P$ in leaves and stems, $P$ uptake in leaves and stems, as well as $P$ availability in soil. $P$ content, uptake, and available were analyzed by composite sampling (Patil 2002). The available P was analyzed by the Bray-1 method, and the $P$ content of leaves and stems was analyzed by wet ashing with $\mathrm{HNO} 3$ and $\mathrm{HClO} 4$.

Plants were harvested twelve weeks after sowing. One day before harvest, $50 \mathrm{~g}$ soil samples were taken as a composite from each experimental unit using a metal spoon placed in the center between the plant stem and edge of the pot. Soil samples were aerated until further analyses for $P$ available. At harvest, roots were washed thoroughly free of soil with tap water and cut from the shoot, and then the fresh and dry weight of shoot and root, $P$ content, and $P$ uptake was measured. The data were analyzed by ANOVA (Analysis of Variance) using the SPSS program. The differences among treatments means were determined by Duncan's Multiple Range Test (DMRT) at $\mathrm{P}<0.05$.

\section{RESULTS AND DISCUSSION}

The growth of oil palm seedlings in the pre-nursery

The results of the analysis in Table 1 show that treatment without compost + lime produced the highest plant height. However, this result did not differ significantly from that of efb compost, without compost and phosphate-solubilizing bacteria. The application without compost as control could produce the lowest plant height and length of leaves. 
Table 1. The effect of efb compost, P-solubilizing bacteria, and lime on the growth of oil palm seedlings in the latosols pre-nursery

\begin{tabular}{lllll}
\hline & \multicolumn{4}{c}{ Application of empty fruit bunches compost } \\
\cline { 2 - 5 } Parameters & $\begin{array}{l}\text { Without compost } \\
\text { (control) }\end{array}$ & Efb compost & $\begin{array}{l}\text { Without compost } \\
+ \text { P bacteria }\end{array}$ & $\begin{array}{l}\text { Without compost } \\
+ \text { lime }\end{array}$ \\
\hline Plant height $(\mathrm{cm})$ & $24.30 \pm 3.5 \mathrm{~b}$ & $25.77 \pm 3.5 \mathrm{ab}$ & $25.71 \pm 4.2 \mathrm{ab}$ & $27.44 \pm 3.4 \mathrm{a}$ \\
Length of leaf $(\mathrm{cm})$ & $18.67 \pm 2.8 \mathrm{c}$ & $19.73 \pm 2.7 \mathrm{bc}$ & $20.38 \pm 3.5 \mathrm{ab}$ & $21.49 \pm 2.9 \mathrm{a}$ \\
Stem diameter $(\mathrm{cm})$ & $0.98 \pm 0.4 \mathrm{a}$ & $0.89 \pm 0.2 \mathrm{a}$ & $0.93 \pm 0.3 \mathrm{a}$ & $0.92 \pm 0.3 \mathrm{a}$ \\
Fresh weight of root $(\mathrm{g})$ & $3.36 \pm 1.4 \mathrm{a}$ & $3.19 \pm 1.4 \mathrm{a}$ & $4.13 \pm 1.4 \mathrm{a}$ & $3.74 \pm 1.2 \mathrm{a}$ \\
Dry weight of root $(\mathrm{g})$ & $1.77 \pm 0.9 \mathrm{a}$ & $1.66 \pm 0.9 \mathrm{a}$ & $2.24 \pm 0.7 \mathrm{a}$ & $1.87 \pm 0.7 \mathrm{a}$ \\
Fresh weight of plant $(\mathrm{g})$ & $4.69 \pm 1.9 \mathrm{a}$ & $4.25 \pm 1.3 \mathrm{a}$ & $4.95 \pm 2.2 \mathrm{a}$ & $5.67 \pm 1.7 \mathrm{a}$ \\
Dry weight of plant $(\mathrm{g})$ & $0.96 \pm 0.4 \mathrm{a}$ & $0.97 \pm 0.4 \mathrm{a}$ & $1.06 \pm 0.5 \mathrm{a}$ & $1.19 \pm 0.4 \mathrm{a}$ \\
Volume of root $(\mathrm{ml})$ & $2.13 \pm 0.8 \mathrm{a}$ & $1.94 \pm 0.6 \mathrm{a}$ & $2.44 \pm 1.2 \mathrm{a}$ & $2.50 \pm 0.6 \mathrm{a}$ \\
\hline
\end{tabular}

Remarks: Means followed by the same letter on the line indicate no significant differences based on Duncan's Multiple Range Test at $p<0.05$

The results of the analysis in Table 1 shows that control, efb compost, without compost + phosphatesolubilizing bacteria, without compost + dolomite lime had the same effect on the stem diameter, fresh weight and dry weight of roots, fresh weight and dry weight of the plant as well as the root volume, except on plant height and the length of the leaf. Treatment without compost + lime yielded the highest height of seedlings and the length of the leaf. Liming plays a crucial role in improving soil fertility and the productivity of acidic dry soil containing high $\mathrm{Al}$ and $\mathrm{Fe}$ elements. It will increase the $\mathrm{pH}$ of latosols, so macronutrients, especially $\mathrm{P}$, are released and available to plants. Plants require Phosphorus as a constituent of ATP and as a source of energy for the process of metabolism. This $P$ nutrient also stimulates the growth and development of fine roots, contributes to the process of seedling growth. Wijanarko and Taufiq (2016) showed that liming increased the number of soybean pods by $48-49 \%$ compared with no lime application on tidal land.

Thus, efb compost can increase the height of seedlings. Several reports summarized by Siregar et al. (2017) indicate that soil phosphate availability is enhanced by additions of organic matter or compost, presumably because of the chelation of polyvalent cations by organic acids and other decay products. The increase of seedling height due to the treatment of phosphate-solubilizing bacteria is estimated to produce not only organic acids, which can improve the availability of $\mathrm{P}$, but also phytohormones from the bacteria. Some phosphate-solubilizing bacteria (PSB) can even produce plant growth regulators or phytohormones, such as indole acetic acid (IAA) and gibberellin (GA). Phosphatesolubilizing bacteria (PSB) can promote the dissolution of insoluble phosphorus $(P)$ in soil, enhancing the availability of soluble $P$. Thus, their application can reduce the consumption of fertilizer and aid in sustainable agricultural development (Wang et al. 2017).

The results of the analysis of Table 2 shows that the $P$ fertilization exerted the same effect as the control fertilization (NPKMg 15-15-6-4 fertilizer and Urea) on growth parameters (height of seedlings, leaf length, fresh weight and dry weight of roots, fresh weight and dry weight of the canopy, as well as root volume) except in stem diameter. The application of RP fertilizers could boost the highest stem diameter. This result did not differ significantly from that of SP-36 fertilizers and the control treatment. The various types of $P$ fertilization with the same amount of P2O5 stimulated the growth of oil palm seedlings in the latosols pre-nursery.

The results in Table 3 showed that the application of without efb compost + lime with RP fertilizers could produce or boost the highest number of leaves. This result did not differ significantly from that of lime and SP36 fertilizer, phosphate-solubilizing bacteria, and SP-36 fertilizer or RP, efb compost, and SP-36 fertilizer or RP, and the control treatment.

Table 2. The effect of $P$ fertilization on the growth of oil palm seedlings in the latosols pre-nursery

\begin{tabular}{lllll}
\hline \multirow{2}{*}{ Parameters } & \multicolumn{3}{c}{ Type of P Fertilizers } \\
\cline { 2 - 5 } & SP-36 & RP & Guano & NPKMg urea (control) \\
\hline Plant height $(\mathrm{cm})$ & $26.34 \pm 4.7 p$ & $26.45 \pm 3.3 p$ & $25.74 \pm 2.6 p$ & $24.68 \pm 4.2 p$ \\
Length of leaf $(\mathrm{cm})$ & $20.45 \pm 3.8 \mathrm{p}$ & $20.78 \pm 3.1 \mathrm{p}$ & $19.96 \pm 2.2 \mathrm{p}$ & $19.09 \pm 3.1 \mathrm{p}$ \\
Stem diameter $(\mathrm{cm})$ & $0.96 \pm 0.3 \mathrm{pq}$ & $1.00 \pm 0.3 \mathrm{p}$ & $0.85 \pm 0.2 \mathrm{q}$ & $0.92 \pm 0.4 \mathrm{pq}$ \\
Fresh weight of root $(\mathrm{g})$ & $3.33 \pm 1.5 \mathrm{p}$ & $3.59 \pm 1.2 \mathrm{p}$ & $3.66 \pm 1.1 \mathrm{p}$ & $3.85 \pm 1.7 \mathrm{p}$ \\
Dry weight of root $(\mathrm{g})$ & $1.76 \pm 0.9 \mathrm{p}$ & $1.82 \pm 0.7 \mathrm{p}$ & $1.92 \pm 0.6 \mathrm{p}$ & $2.05 \pm 1.1 \mathrm{p}$ \\
Fresh weight of plant $(\mathrm{g})$ & $4.97 \pm 1.8 \mathrm{p}$ & $4.89 \pm 1.9 \mathrm{p}$ & $4.77 \pm 1.6 \mathrm{p}$ & $4.94 \pm 2.2 \mathrm{p}$ \\
Dry weight of plant $(\mathrm{g})$ & $1.08 \pm 0.4 \mathrm{p}$ & $1.06 \pm 0.5 \mathrm{p}$ & $1.02 \pm 0.3 \mathrm{p}$ & $1.04 \pm 0.4 \mathrm{p}$ \\
Volume of root $(\mathrm{ml})$ & $2.13 \pm 0.7 \mathrm{p}$ & $2.44 \pm 0.6 \mathrm{p}$ & $2.00 \pm 0.6 \mathrm{p}$ & $2.44 \pm 1.3 \mathrm{p}$
\end{tabular}

Remarks: Means followed by the same letter on the line indicate no significant differences based on Duncan's Multiple Range Test at $p<0.05$ 
Table 3. Interaction between efb compost and $P$ fertilizer in terms of the number of leaves of oil palm seedlings in the latosols pre-nursery

\begin{tabular}{lllll}
\hline \multirow{2}{*}{ Application of efb compost } & \multicolumn{4}{c}{ Type of P Fertilizers } \\
\cline { 2 - 5 } & SP-36 & RP & Guano & NPKMg urea (control) \\
\hline Without Compost (control) & $4.44 \pm 0.5 \mathrm{bc}$ & $4.44 \pm 0.5 \mathrm{bc}$ & $4.78 \pm 0.4 \mathrm{abc}$ & $4.44 \pm 0.5 \mathrm{bc}$ \\
Efb compost & $4.67 \pm 0.5 \mathrm{abc}$ & $4.67 \pm 0.5 \mathrm{abc}$ & $4.33 \pm 0.5 \mathrm{bc}$ & $4.22 \pm 0.7 \mathrm{c}$ \\
Without compost + P bacteria & $4.89 \pm 0.3 \mathrm{ab}$ & $4.56 \pm 0.5 \mathrm{abc}$ & $4.33 \pm 0.5 \mathrm{bc}$ & $4.67 \pm 0.7 \mathrm{abc}$ \\
Without compost + lime & $4.67 \pm 0.5 \mathrm{abc}$ & $5.11 \pm 0.3 \mathrm{a}$ & $4.67 \pm 0.5 \mathrm{abc}$ & $4.22 \pm 0.7 \mathrm{c}$ \\
\hline
\end{tabular}

Remarks: Means followed by the same letter are not significantly different according to the Duncan's Multiple Range Test at $p<0.05$.

Nutrient content of $P$ and $P$ uptake of palm seedlings in the latosol pre-nursery

The results of the analysis in Table 4 showed that the application of phosphate-solubilizing bacteria with SP-36 fertilizer could produce the highest content of $P$ nutrient of leaves, followed by lime with SP-36 or RP fertilizers, efb compost, and RP fertilizers. The application of efb compost with RP fertilizers could produce the highest $P$ nutrient content of plant stems, followed by phosphatesolubilizing bacteria with SP-36 fertilizers, lime, and SP36 or RP fertilizers. The application of efb with guano fertilizer did not have little impact on the $P$ nutrient of leaves and stems.

The application of lime (20 g seedlings $\left.^{-1}\right)$ with SP-36 fertilizers could boost the highest number of $P$ uptake of leaves and stems. These results were slightly higher from that of efb compost with RP fertilizers. The application of efb with guano fertilizer did not have little impact on $P$ uptakes of leaves and stems. The result shows that, although the P level of leaves was lower, the $P$ uptake of leaves was greater than that of $P$ stems. This is possibly because the dry weight of the leaf is greater than that of the stems. Liming in acid soil improves aggregate stability and increases the bioavailability of phosphorus $(\mathrm{P})$, calcium $(\mathrm{Ca})$, magnesium $(\mathrm{Mg})$, and molybdenum (Mo) nutrients. (Olego et al. 2014).

The result of the $P$ availability analysis in Table 4 showed that the highest available $P$ was obtained in the combination of without efb compost + PSB with SP-36 fertilizer, which was $631.1 \%$ compared to control (without efb compost and NPKMg, urea). The lowest in the combination of without efb compost + lime with (NPKMg, urea). The treatment without efb compost + lime with SP36 fertilizer increased $P$ uptake of leaves by $55.6 \%$ and stem by $47.1 \%$ compared to control. Thus, liming increased soil $\mathrm{pH}$, so all the solubility of all the macro nutrients, including $\mathrm{P}$ and $\mathrm{Ca}$, increased. In this case, Calcium (Ca) plays an important role in the development of young roots, thereby improving plant nutrient uptake. Phosphorus is a limiting factor in crop productivity in acid soils (latosols used for this study has a pH of 4.5); this is because soluble inorganic $\mathrm{P}$ was fixed by $\mathrm{Al}$ and $\mathrm{Fe}$ so that the availability of $P$ in the soil is a little.

Table 4. Nutrient content of $P$ and $P$ uptake of palm seedlings in the latosols pre-nursery as a response of efb compost and $\mathrm{P}$ fertilization

\begin{tabular}{|c|c|c|c|c|c|}
\hline Treatment & $\begin{array}{l}\text { P content of leaves } \\
(\%)\end{array}$ & $\begin{array}{l}\text { P content of stem } \\
(\%)\end{array}$ & $\begin{array}{l}\text { P uptake of leaves } \\
g_{\text {seedling }}^{-1}\end{array}$ & $\begin{array}{l}\text { P uptake of stem g } \\
\text { seedling }^{-1}\end{array}$ & $\begin{array}{l}\text { P available of soil } \\
(\mathrm{ppm})\end{array}$ \\
\hline TOP1 & 0.44 & 0.59 & 0.0026 & 0.0012 & 11.03 \\
\hline TOP2 & 0.46 & 0.68 & 0.0030 & 0.0016 & 9.73 \\
\hline TOP3 & 0.45 & 0.61 & 0.0036 & 0.0018 & 8.23 \\
\hline TOP4(as control) & 0.45 & 0.62 & 0.0036 & 0.0017 & 8.40 \\
\hline T1P1 & 0.42 & 0.59 & 0.0029 & 0.0015 & 14.01 \\
\hline T1P2 & 0.50 & 0.70 & 0.0044 & 0.0023 & 14.09 \\
\hline T1P3 & 0.38 & 0.42 & 0.0023 & 0.0010 & 13.69 \\
\hline T1P4 & 0.41 & 0.50 & 0.0027 & 0.0011 & 13.45 \\
\hline T2P1 & 0.52 & 0.67 & 0.0038 & 0.0020 & 61.41 \\
\hline T2P2 & 0.39 & 0.47 & 0.0028 & 0.0012 & 42.89 \\
\hline T2P3 & 0.46 & 0.61 & 0.0033 & 0.0016 & 49.83 \\
\hline $\mathrm{T} 2 \mathrm{P} 4$ & 0.43 & 0.54 & 0.0039 & 0.0018 & 57.45 \\
\hline T3P1 & 0.51 & 0.62 & 0.0056 & 0.0025 & 10.28 \\
\hline T3P2 & 0.51 & 0.63 & 0.0041 & 0.0021 & 9.82 \\
\hline Т3Р3 & 0.48 & 0.60 & 0.0040 & 0.0018 & 6.35 \\
\hline T3P4 & 0.49 & 0.62 & 0.0035 & 0.0017 & 6.18 \\
\hline
\end{tabular}

Remarks: (T0: without compost, T1: efb compost, T2: without compost + P solubilizing bacteria, T3: without compost + lime, P1 : SP-36, P2 : RP P3 : guano, P4 : NPKMg + urea), P content, uptake and available were analyzed by composite sampling. 
The application of lime, organic matter and fertilizer could reduce soil acidity, Al toxicity, and deficiency of nutrients. The application of lime on acid soils could increase the $\mathrm{pH}$ of the soil solution and availability of $\mathrm{P}$ (Chao et al. 2014). Besides, phosphate-solubilizing bacteria are known to have the ability to dissolve $P$ bounded in the soil; phosphate-solubilizing microorganisms might play a pivotal role in modifying insoluble $P$ into soluble $P$ by producing extracellular enzymes and organic acids to improve $P$ availability in the soil and reduce the pathogenicity of plant pathogens (Krishnakumar et al. 2020).

The $\mathrm{P}$ availability of efb compost treatment at a dose of $15 \%$ volume is lower than phosphate-solubilizing bacteria. The dose of efb compost might be insufficient to increase the availability of $P$ in the soil. Further, organic compounds were derived from plant residues that contain $\mathrm{P}$ elements. Therefore, $\mathrm{P}$ content will be increased when organic compounds were added to the soil. A previous study by Rosenani et al. (2016) conducted in Selangor, Malaysia, reported that prenursery polybag medium amended with oil palm waste compost up to $70 \%$ increased oil palm seedling growth. Meanwhile, $72 \%$ of the compost mixed with topsoil could produce the best planting material with respect to the high oil palm seedlings growth and development as well as greater nutrient uptake.

\section{CONCLUSIONS}

The results showed that the application of empty fruit bunch compost had less effect on $\mathrm{P}$ soil availability, $\mathrm{P}$ uptake of leaves and stems compared with the application of phosphate-solubilizing bacteria and lime with SP-36 fertilizer. The application of efb, PSB, lime, and control resulted in the same growth of oil palm seedlings in the prenursery, except on plant height and the length of leaf, lime applications provide the best results. Various types of $P$ fertilizer led to the same growth of oil palm seedlings except for stem diameter. The combination of without efb + lime and RP fertilizer produces the highest number of leaves.

\section{REFERENCES}

Chao S, Changli L, Yun Z, Hongbing H. 2014. Impact of animal manure addition on agricultural lime weathering in acidic soil: $\mathrm{Ph}$ dependence and $\mathrm{Co} 2$ independence of agricultural lime weathering. Procedia Earth Planet Sci. 10:405-409. doi: 10.1016/j.proeps.2014.08.072.

Corley RHV, Tinker PB. 2015. The oil palm. Chichester, UK: John Wiley \& Sons, Ltd. http://doi.wiley.com/10.1002/9781118953297.

Damanik M, Hasibuan BE, Fauzi S, Hamidah H. 2011. Soil fertility and fertilization. USU Press. Medan.

Directorate General of Estate Crops. 2016. Tree crop estate statistics of Indonesia 2015-2017 (palm oil). Jakarta. http://ditjenbun. pertanian.go.id.
Hastuti PB, Rohmiyati SM. 2016. Peningkatan efisiensi pemupukan pada pembibitan kelapa sawit melalui pemanfaatan limbah perkebunan kelapa sawit. Agrivet. 22(2):1-10.

Krishnakumar S, Bai VDM, Rajan RA. 2020. Evaluation of Phosphate Solubilizing Microorganisms (PSMs) from Rhizosphere soil of different crop plants and its antagonistic activity. J Microbiol Biotechnol Food Sci. 9(4):412-415.

Lestari W, Linda TM, Martina A. 2011. Kemampuan bakteri pelarut fosfat isolat asal Sei Garo dalam penyediaan fosfat terlarut dan serapannya pada tanaman kedelai. Biospecies. 4(2):1-5.

Maftu'ah E, Maas A, Syukur A, Purwanto BH. 2013. Efektivitas amelioran pada lahan gambut terdegradasi untuk meningkatkan pertumbuhan dan serapan NPK tanaman jagung manis (Zea mays L. var. saccharata). J Agron Indones (Indonesian J Agron. 41(1).

Olego MÁ, De Paz JM, Visconti F, Garzón JE. 2014. Predictive modelling of soil aluminium saturation as a basis for liming recommendations in vineyard acid soils under Mediterranean conditions. Soil Sci Plant Nutr. 60(5):695-707. doi:10.1080/00380768.2014.930333.

Patil GP. 2002. Composite sampling. In: El-Shaarawi $\mathrm{AH}$, Piegorsch WW, editors. Encyclopedia of Environmetrics. Volume 1. Chichester, UK: John Wiley \& Sons, Ltd. p. 387-391.

Ritonga M, Sitorus B, Sembiring M. 2015. Perubahan bentuk $P$ oleh mikroba pelarut fosfat dan bahan organik terhadap p-tersedia dan produksi kentang (Solanum tuberosum I.) pada tanah Andisol terdampak erupsi Gunung Sinabung. J Agroekoteknologi Univ Sumatera Utara. 4(1):16411650.

Rosenani AB, Rovica R, Cheah PM, Lim CT. 2016. Growth performance and nutrient uptake of oil palm seedling in prenursery stage as influenced by oil palm waste compost in growing media. Int $\mathrm{J}$ Agron. 2016:1-8. doi:10.1155/2016/6930735.

Siddiquee S, Shafawati SN, Naher L. 2017. Effective composting of empty fruit bunches using potential Trichoderma strains. Biotechnol Reports. 13:1-7. doi: 10.1016/j.btre.2016.11.001.

Siddiqui Y, Meon S, Mohd RI, Rahmani M, Ali A. 2009. Efficient conversion of empty fruit bunch of oil palm into fertilizer enriched compost. Asian J Microbiol Biotechnol Environ Sci. 11(2):1-6.

Siregar P, Fauzi, Supriadi. 2017. Pengaruh pemberian beberapa sumber bahan organik dan masa inkubasi terhadap beberapa aspek kimia kesuburan tanah Ultisol: Effect of Giving Some Organic Matter and Incubation Period to some Chemical Fertility Aspects of Ultisol. J Online Agroekoteknologi. 5(2):256-264. 
Walsh E, McDonnell KP. 2012. The influence of added organic matter on soil physical, chemical, and biological properties: a small-scale and short-time experiment using straw. Arch Agron Soil Sci. 58(sup1): S201-S205. doi:10.1080/03650340.2012.697999.

Wang Z, Xu G, Ma P, Lin Y, Yang X, Cao C. 2017. Isolation and characterization of a PhosphorusSolubilizing Bacterium from Rhizosphere soils and its colonization of Chinese Cabbage (Brassica campestris ssp. chinensis). Front Microbiol. 8. doi:10.3389/fmicb.2017.01270.

Wijanarko A, Taufiq A. 2016. Effect of lime application on soil properties and soybean yield on tidal land. AGRIVITA J Agric Sci. 38(1):14-23. doi:10.17503/agrivita.v38i1.683. 